\title{
Adsorption Capacity of a Volcanic Rock-Used in Constructed Wetlands-For Carbamazepine Removal, and Its Modification with Biofilm Growth
}

\author{
Allan Tejeda ${ }^{1}$, Arturo Barrera ${ }^{2}$ and Florentina Zurita ${ }^{1, *}$ \\ 1 Quality Environmental Laboratory, Centro Universitario de la Ciénega, University of Guadalajara, Ocotlán, \\ Jalisco 47820, Mexico; allanteor@hotmail.com \\ 2 Laboratory of Catalytic Nanomaterials, Centro Universitario de la Ciénega, University of Guadalajara, \\ Ocotlán, Jalisco 47820, Mexico; arturo.barrera@cuci.udg.mx \\ * Correspondence: fzurita2001@yahoo.com; Tel.: +52-392-925-9400
}

Received: 26 August 2017; Accepted: 15 September 2017; Published: 20 September 2017

\begin{abstract}
In this study, the aim was to evaluate the adsorption capacity of a volcanic rock commonly used in Mexico as filter medium in constructed wetlands (locally named tezontle) for carbamazepine (CBZ) adsorption, as well as to analyze the change in its capacity with biofilm growth. Adsorption essays were carried out under batch conditions by evaluating two particle sizes of tezontle, two values of the solution $\mathrm{pH}$, and two temperatures; from these essays, optimal conditions for carbamazepine adsorption were obtained. The optimal conditions ( $\mathrm{pH} 8,25^{\circ} \mathrm{C}$ and $0.85-2.0 \mathrm{~mm}$ particle-size) were used to evaluate the adsorption capacity of tezontle with biofilm, which was promoted through tezontle exposition to wastewater in glass columns, for six months. The maximum adsorption capacity of clean tezontle was $3.48 \mu \mathrm{g} / \mathrm{g}$; while for the tezontle with biofilm, the minimum value was $1.75 \mu \mathrm{g} / \mathrm{g}$ (after the second week) and the maximum, was $3.3 \mu \mathrm{g} / \mathrm{g}$ (after six months) with a clear tendency of increasing over time. The adsorption kinetic was fitted to a pseudo-second model for both tezontle without biofilm and with biofilm, thus indicating a chemisorption process. On clean tezontle, both acid active sites (AAS) and basic active sites (BAS) were found in 0.087 and $0.147 \mathrm{meq} / \mathrm{g}$, respectively. The increase in the adsorption capacity of tezontle with biofilm, along the time was correlated with a higher concentration of BAS, presumably from a greater development of biofilm. The presence of biofilm onto tezontle surface was confirmed through FTIR and FE-SEM. These results confirm the essential role of filter media for pharmaceutical removal in constructed wetlands (CWs).
\end{abstract}

Keywords: pharmaceuticals; micropollutant removal; tezontle; filter media; active sites

\section{Introduction}

Carbamazepine (CBZ) is a drug extensively used worldwide in the treatment of a variety of mental disorders, neuralgia, and seizure disorders [1,2]. In the last two decades, this drug has been found along with a huge diversity of pharmaceuticals in aquatic environments. Moreover, according to different studies, CBZ is the pharmaceutical most frequently detected in water bodies around the world [3,4] so that it has been proposed as an anthropogenic marker in such environments [5]. This situation is mainly a consequence of CBZ's poor removal in conventional wastewater treatment plants (WWTP), which is generally lower than $10 \%$. The effluents of municipal WWTPs are considered the main route for pharmaceutical release into the environment $[6,7]$.

In recent years, the removal of pharmaceutical compounds in constructed wetlands $(\mathrm{CW})$ have been the aim in many studies worldwide [8]. Although the removal efficiencies for many drugs in such systems have been found to be similar or much higher than those removals achieved in conventional WWTPs, the removal of CBZ has been very low, varying in the range of $20-30 \%$ with an average 
efficiency of lower than 30\% [6]. However, in a recent study carried out by this research group, removal efficiencies of $62.5 \%$ and $59 \%$ were found in two two-stage hybrid constructed wetlands configured with horizontal subsurface flow wetland (HSSFW), followed by stabilization ponds and HSSFW, then followed by vertical subsurface flow wetland, respectively [9]. These results were achieved under a subtropical climate by using ornamental species as emergent vegetation in conjunction with a porous-local ground volcanic rock as filter medium, commonly named tezontle. In Mexico, this is the substrate most frequently used in CWs.

On the other hand, it has been reported that the main mechanisms for CBZ removal in constructed wetlands, include microbial degradation, plant uptake, and adsorption [10], which are not completely elucidated due to the fact that most studies have been focused only on the inlet and outlet loads [8]. In general, adsorption as a removal process for pharmaceuticals has been extensively assessed through the use of different adsorbents; among those adsorbents recently evaluated are commercial activated carbons [11], silica-based materials [12], chitosan-based magnetic composite [13], ion-exchange resins [14], clay minerals [15], etc. Nevertheless, commonly used filter media in CWs have been scarcely evaluated as adsorbents for pharmaceutical removal $[8,16]$; as a result, their contribution for each specific drug removal, such as CBZ, is almost unknown.

Among the few reported studies is that performed by Dordio et al. [2] who evaluated light expanded clay aggregates (LECA) for CBZ removal as a single compound and as a mixture of three compounds (CBZ, ibuprofen, and clofibric acid), obtaining higher removal efficiencies for CBZ in all of the tested conditions in comparison to the other two drugs. In another study, Matamoros et al. [17] quantified sorption on gravel used as substrate in HSSFWs, finding a higher sorption of CBZ in comparison to clofibric acid and ibuprofen; they attributed such results to the presence of biofilm covering the gravel bed. From these few studies, it is evident the relevance of sorption as a mechanism for CBZ removal and also the necessity of evaluating filter media used in CWs, such as the volcanic rock we use in Mexico, which probably contributed to the high removal of CBZ obtained in a previous study [9], as mentioned before. Therefore, the aim of this study was to evaluate the sorption capacity of ground tezontle for CBZ removal, as well as to evaluate the change in its capacity with the presence of biofilm developed through its exposition to wastewater.

\section{Materials and Methods}

\subsection{Material Preparation}

The material was purchased from a construction material store. In Mexico, tezontle is a porous material extensively used in construction. Approximately $5 \mathrm{~kg}$ of ground tezontle were washed with tap water in order to completely remove any dirt and dust, and then dried at $110{ }^{\circ} \mathrm{C}$ for $24 \mathrm{~h}$. After drying, the material was left to reach room temperature and then it was sieved through appropriate AST sieves in order to classify it in two different particle sizes, i.e., $0.85-2 \mathrm{~mm}$ (PS1) and 4-4.75 mm (PS2). Once classified and separated according to the particle size, the material was stored in a desiccator at room temperature until its use to perform the adsorption experiments.

\subsection{Characterization of the Ground Tezontle}

The particle size distribution was determined through the dry-sieving technique $[2,18]$. By means of a grain-size distribution plot, $\mathrm{d}_{10}$ and $\mathrm{d}_{60}$ were estimated, while the uniformity coefficient was obtained as the ratio between $\mathrm{d}_{60}$ and $\mathrm{d}_{10}$ [2]. Additionally, the material porosity and bulk density was calculated according to Brix et al. [19]. On the other hand, tezontle structural properties were analyzed by X-ray diffraction (XRD) using a STOE diffractometer (Stoe, Darmstadt, Germany) with $\mathrm{Cu} \mathrm{K \alpha}$ anode $(\lambda=1.5406 \mathrm{~nm})$. In addition, textural properties of tezontle, such as the average pore diameter (APD), total pore volume $\left(\mathrm{VP}_{\mathrm{T}}\right)$, and $\mathrm{N}_{2}$ adsorption/desorption isotherms were determined by $\mathrm{N}_{2}$-physisorption at the saturation temperature of liquid nitrogen $\left(-196.5^{\circ} \mathrm{C}\right)$ through the use of an 
Autosorb gas sorption system (IQ model from Quantachrome, Boynton Beach, FL, USA). The specific surface area $\left(\mathrm{S}_{\mathrm{BET}}\right)$ was calculated according to the Brunauer-Emmet-Teller (BET) equation.

\subsection{Adsorption Kinetic Assays of CBZ onto Tezontle without Biofilm}

In order to find out the best conditions for CBZ adsorption (particle size, temperature, and $\mathrm{pH}$ ), adsorption experiments were performed by adding $1 \mathrm{~g}$ of tezontle to glass flasks containing $100 \mathrm{~mL}$ of carbamazepine (99\% purity, Sigma-Aldrich, Saint Louis, MO, USA) solution at a concentration of $250 \mu \mathrm{g} / \mathrm{L}$, buffered with $0.01 \mathrm{M}$ of phosphate [20] in order to maintain the $\mathrm{pH}$ at the desired level, which was adjusted by using $\mathrm{H}_{2} \mathrm{SO}_{4}$ or $\mathrm{NaOH} 0.1 \mathrm{~N}$. The flasks were stirred magnetically at $200 \mathrm{rpm}$ for the evaluation of CBZ adsorption onto tezontle for 0.5, 1, 1.5, 2, 3, and $4 \mathrm{~h}$. These assays were performed by triplicate with the two different particle size of tezontle, PS1 and PS2, at two different temperatures, $16^{\circ} \mathrm{C}$ and $25^{\circ} \mathrm{C}$, and at two levels of $\mathrm{pH}, 6$ and 8 (Figure 1).

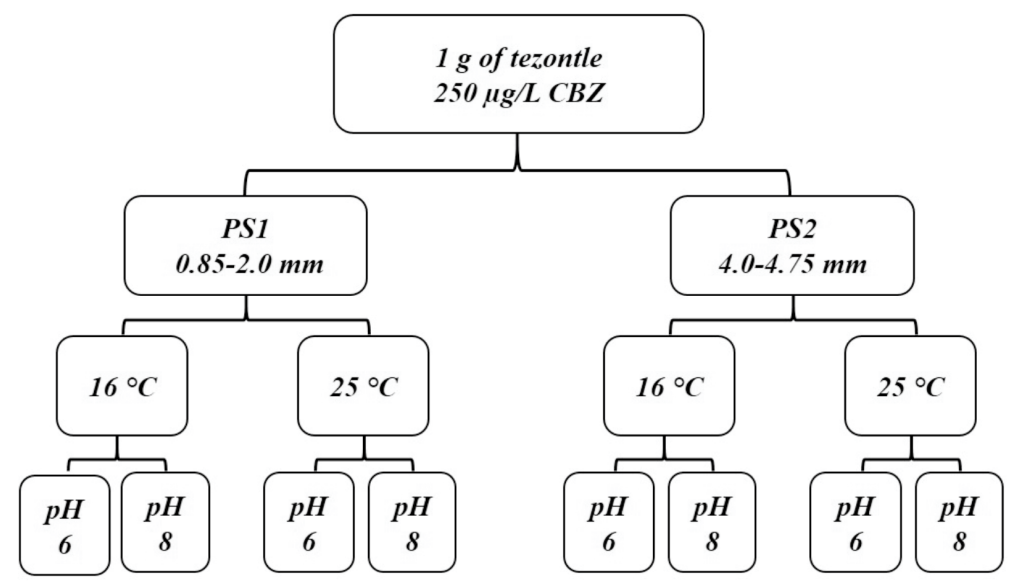

Figure 1. Experiment design for the adsorption kinetic assays of carbamazepine (CBZ) on tezontle without biofilm.

\subsection{Adsorption Kinetic Assays of CBZ onto Tezontle with Biofilm}

The growth of biofilm on the tezontle surface was carried out in 15 glass columns (dimensions, diameter $=2 \mathrm{~cm}$; large $=25 \mathrm{~cm}$ ) that were packed with the filter medium. The particle size used was that with which the higher adsorption capacity was obtained from the assays, as described in the previous section. All of the columns were fed with sedimented wastewater generated in the campus of Centro Universitario de la Ciénega with a flow rate of $0.19 \pm 0.02 \mathrm{~L} / \mathrm{min}$ (controlled by a valve for each column) and a hydraulic retention time of $13.79 \pm 1.38 \mathrm{~s}$. The wastewater was stored in a $10 \mathrm{~L}$-plastic container and recirculated for 15 days by means of an $18 \mathrm{~W}$-fountain pump and then replaced. An upward flow was maintained by feeding the wastewater through a tubing system joined to the bottom of each column; the wastewater was returned to the plastic container by tubings located at the top of the columns. This type of flow was used in order to keep flooding conditions inside the columns, as well as to maintain a constant flow rate.

Wastewater characterization included measurements of chemical oxygen demand (COD), biochemical oxygen demand (BOD), total nitrogen, phosphorus, total suspended solids (TSS), conductivity, and $\mathrm{pH}$, which were determined as described in the Standard Methods for the examination of Water and Wastewater [21]. A column was removed from the whole experiment (15 glass columns) every week during 12 weeks and then, every month. The tezontle inside the columns was removed and deactivated by UV-radiation for $30 \mathrm{~min}$ from a distance of $12.0 \mathrm{~cm}$ [22] using a SPECTROLINE lamp, EA-160, (Spectronics Corporation, Westbury, NY, USA); immediately after, the tezontle was dried at $50{ }^{\circ} \mathrm{C}$ by $3 \mathrm{~h}$. Then, the material was kept in a desiccator until its use to carry out adsorption kinetic experiments, as described in Section 2.3, under the optimum conditions 
determined in the essays described in that same section. In addition, a sample of this material was analyzed by Fourier Transform Infrared Spectroscopy (FTIR) and by Field Emission Scanning Electron Microscopy (FE-SEM) to confirm the presence of biofilm. Surface active site concentration (SASC) was also determined in each sample. For FTIR analysis, a Thermo Nicolet Nexus 470 spectrophotometer (Artisan Technology Group, Champaing, IL, USA) was used as well as the KBr method, while the FE-SEM micrographs were obtained by a MIRA 3 LMU Tescan microscope (TESCAN, Brno, South Moravian, Czech Republic) using a thin conductive film of gold on the sample surface and a current of $10 \mathrm{kV}$ [2]. Finally, the SASC was quantified by the Boehm titration conventional method [23,24]. In all of these analyses a sample of tezontle without biofilm was included as a reference.

\subsection{Aqueous Samples Preparation and CBZ Detection}

From each essay, $100 \mathrm{~mL}$ of the supernatant was taken and filtered through a $20 \mu \mathrm{m}$ filter paper (Whatman 41, Whatman Inc., Piscataway, NJ, USA) ) and then through a $1.6 \mu \mathrm{m}$ GF/A Whatman fiber glass filter. After that, CBZ was extracted from the aqueous sample by solid phase extraction (SPE) method using Phenomenex Strata-X (200 mg/ 6 cc) cartridges (Phenomenex, Torrance, CA, USA). The cartridges were conditioned with $5 \mathrm{~mL}$ of methanol and $10 \mathrm{~mL}$ of deionized water at a flow rate of $1.5-2 \mathrm{~mL} / \mathrm{min}$. Then, the aqueous sample was passed through the cartridge at the same flow rate. In order to remove any impurity, the cartridges were washed with $5 \mathrm{~mL}$ of deionized water and dried under vacuum for one hour. Thereafter, CBZ was eluted with $10 \mathrm{~mL}$ of methanol. Finally, the samples were filtered through a $0.2 \mu \mathrm{m}$ PTFE filter. CBZ detection were performed by a Waters HPLC as described by [9].

\subsection{Statistical Analysis}

A factorial experimental design, specifically $2^{3}$, was used to evaluate the adsorption kinetic assays of CBZ in aqueous solution by tezontle. The three analyzed factors and their corresponding levels were: particle size (PS1 and PS2), $\mathrm{pH}(6$ and 8$)$ and temperature $\left(16\right.$ and $\left.25^{\circ} \mathrm{C}\right)$. The analysis of variance (ANOVA) was carried out using the STATGRAPHICS CENTURION XVII software (XVII, StatPoint Technologies, Inc., Warrenton, VA, USA). A significance level of $p=0.05$ was used for all statistical tests and values reported are the average \pm standard error of the mean.

\section{Results and Discussion}

\subsection{Structural and Textural Properties of the Ground Tezontle}

The structural and textural properties of the material used in this study are shown in Table 1. According to the particle size distribution, the ground tezontle has a wide particle size distribution, with $92.73 \%$ of the material having diameters between 0.425 and $4 \mathrm{~mm}$. With regard to $\mathrm{d}_{10}, \mathrm{~d}_{60}$, and the uniformity coefficient, they fall into the range of recommendable values for filter media used in CWs [25]. In addition, the apparent porosity was more than $50 \%$, which is higher than those values reported for gravel; in this way, ground tezontle exhibits advantages as a support matrix in CWs, because, the higher amount of void space, the better the hydraulic conductivity [2].

Table 1. Structural and textural characteristics of ground tezontle.

\begin{tabular}{cc}
\hline $\mathrm{d}_{10}(\mathrm{~mm})$ & 0.48 \\
$\mathrm{~d}_{60}(\mathrm{~mm})$ & 1.9 \\
Uniformity coefficient, $\mathrm{U}$ & 3.95 \\
Apparent porosity $/$ void space $(\%)$ & 56.2 \\
Bulk density $\left(\mathrm{kg} / \mathrm{m}^{3}\right)$ & 1047 \\
BET specific surface area, $\mathrm{S}_{\mathrm{BET}}\left(\mathrm{m}^{2} / \mathrm{g}\right)$ & 1.36 \\
Total pore volume, $\mathrm{VP}_{\mathrm{T}}\left(\mathrm{cm}^{3} / \mathrm{g}\right)$ & 0.008 \\
Average pore diameter, $\mathrm{APD}(\mathrm{nm})$ & 26.64 \\
\hline
\end{tabular}


On the other hand, as expected, the BET specific surface area was very small in comparison to adsorbents prepared or synthetized for drug removal but alike to the value reported by Alemayehu \& Lennartz [26] for a similar volcanic scoria. In addition, the $\mathrm{N}_{2}$ adsorption-desorption isotherm of tezontle (Figure 2) was of the type IV with a hysteresis loop of H3-type, according to the IUPAC classification [27]. The hysteresis loop of H3-type indicates the presence of non-rigid aggregates of plate-like particles giving rise to slit-type shaped pores [28]. The pore sizes calculated from the desorption branch of $\mathrm{N}_{2}$ sorption isotherm were in the mesopore range with values between 2 and $50 \mathrm{~nm}$, which is in line with the values reported by Vilchis-Granados et al. [29]. Finally, the X-ray diffraction pattern of tezontle evaluated in this study (Figure 3) revealed the crystalline structure of the material with crystalline peaks located at $2 \theta$ angles of $21.6^{\circ}, 27.5^{\circ}$, and $35.3^{\circ}$. The diffraction peak at $2 \theta=21.6^{\circ}$ corresponds to the plane (110) of goethite $(\mathrm{FeO}(\mathrm{OH}))$, while the peak at $27.5^{\circ}$ belongs to the plane (101) of quartz $\left(\mathrm{SiO}_{2}\right)$ according to Brooks et al. [30]. On the other hand, the peak at $35.3^{\circ}$ corresponds to the crystalline plane (110) of hematite $\left(\mathrm{Fe}_{2} \mathrm{O}_{3}\right)$ according to Farahmandjou \& Soflaee [31]. These results, are in line to those crystalline planes reported for tezontle by Ponce et al. [32] who proposed a preliminary composition consisted mainly of quartz $\left(\mathrm{SiO}_{2}\right)$ and ferric oxides like hematite $\left(\mathrm{Fe}_{2} \mathrm{O}_{3}\right)$.

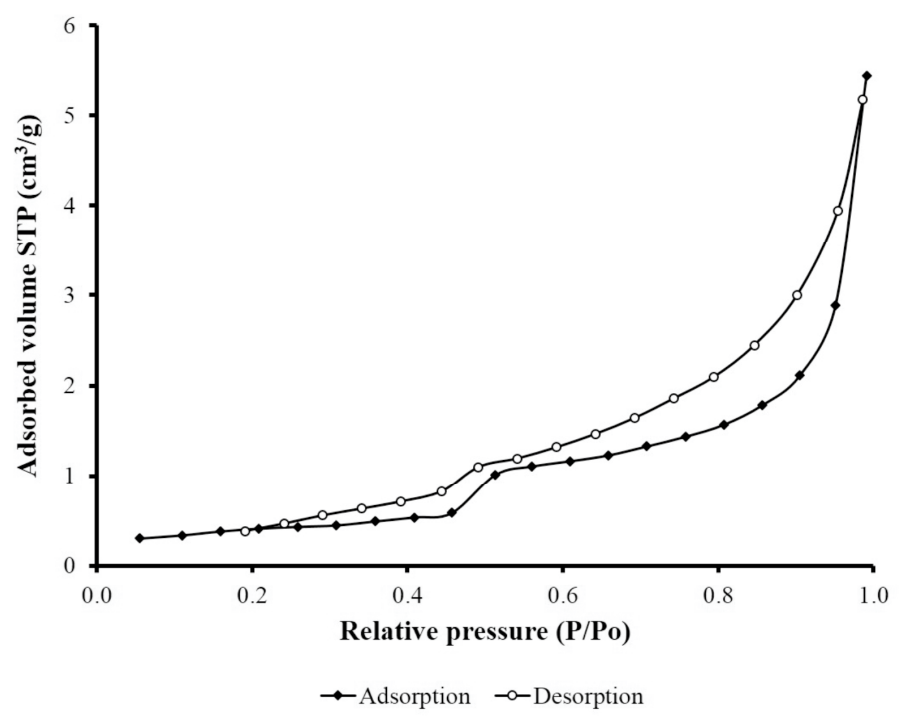

Figure 2. $\mathrm{N}_{2}$ adsorption-desorption isotherm of tezontle.

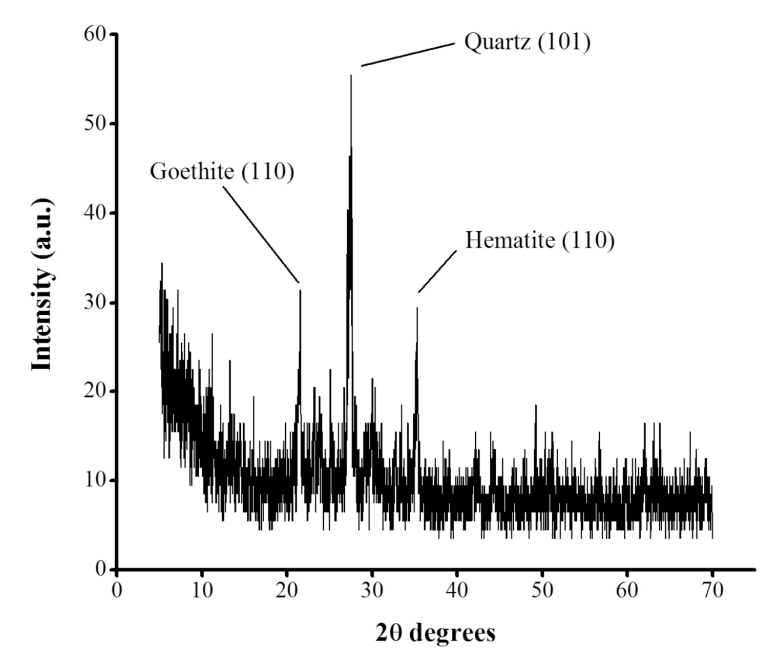

Figure 3. X-ray diffraction (XRD) pattern of tezontle. 


\subsection{Adsorption Kinetics of CBZ onto Tezontle without Biofilm}

The kinetics of CBZ adsorption by tezontle under the different assessed conditions showed a similar behavior with respect to the time that the equilibrium was accomplished (Figure 4 ). With regard to the reached equilibrium concentrations, they showed in general, a low adsorption capacity of tezontle, with small variations at $16^{\circ} \mathrm{C}$ irrespective of $\mathrm{pH}$ or particle size (Table 2); higher variations were observed at $25{ }^{\circ} \mathrm{C}$. However, for both temperatures, the adsorption capacity of tezontle was higher with PS1; such results were expected, since it is well known that smaller particle sizes have larger surface areas available for adsorbate-adsorbent interactions.
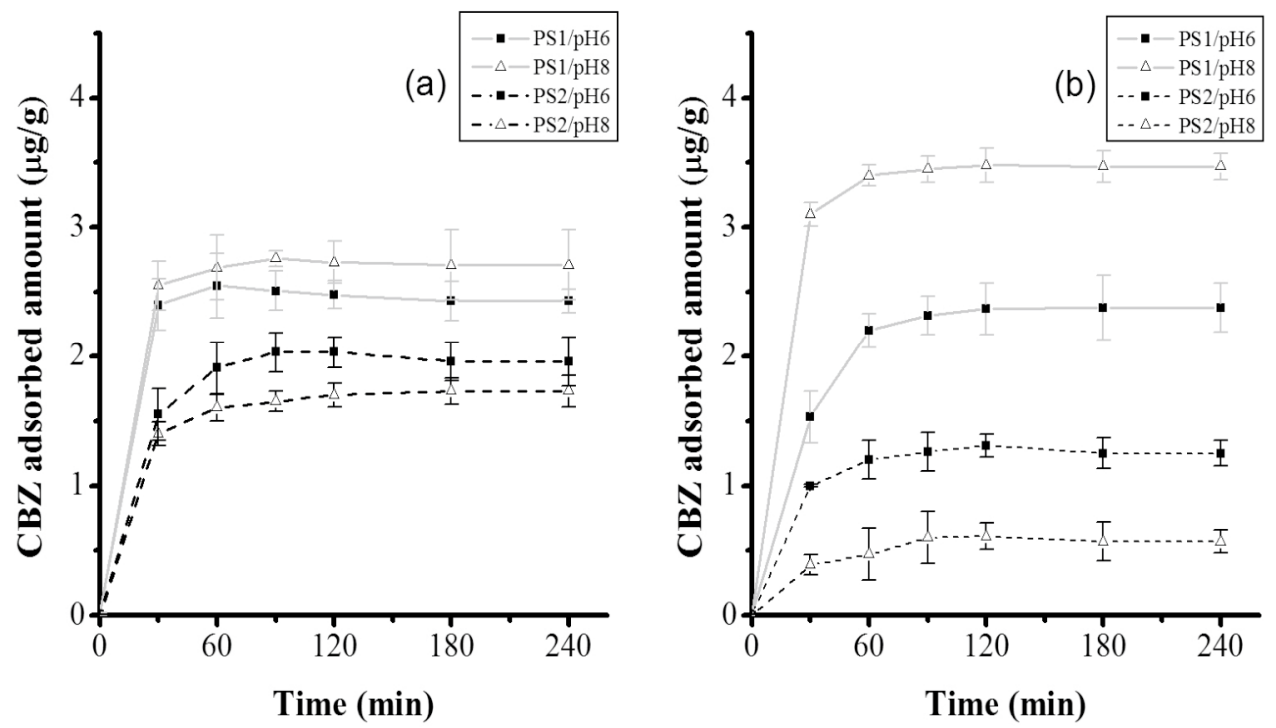

Figure 4. Adsorption kinetics of $\mathrm{CBZ}$ at (a) $16^{\circ} \mathrm{C}$ and (b) $25^{\circ} \mathrm{C}$ onto two particle sizes of tezontle (PS1, PS2) at $\mathrm{pH} 6$ and $\mathrm{pH} 8$.

Table 2. Equilibrium adsorption capacity $\left(\mathrm{q}_{\mathrm{e}}\right)$ and its equivalent removal percentage at the different levels of particle size, $\mathrm{pH}$ and temperature.

\begin{tabular}{cccccc}
\hline Temperature & Parameter & PS1/pH 6 & PS1/pH 8 & PS2/pH6 & PS2/pH8 \\
\hline \multirow{2}{*}{$16^{\circ} \mathrm{C}$} & qe $(\mu \mathrm{g} / \mathrm{g})$ & 2.48 & 2.73 & 2.03 & 1.7 \\
& Removal \% & 9.7 & 10.9 & 8.1 & 6.8 \\
\multirow{2}{*}{$25^{\circ} \mathrm{C}$} & $\mathrm{qe}(\mu \mathrm{g} / \mathrm{g})$ & 2.3 & 3.48 & 1.3 & 0.61 \\
& Removal \% & 9.3 & 14.67 & 5.2 & 2.5 \\
\hline
\end{tabular}

The mathematical model of the factorial design [33] used to find the optimal conditions for CBZ removal by tezontle is shown in Equation (1). In addition, the experimental design along with the data obtained in the CBZ adsorption experiments are shown in Table 3.

$$
y_{i j k l}=\mu+\tau_{i}+\beta_{j}+\gamma_{k}+(\tau \beta)_{i j}+(\tau \gamma)_{i k}+(\beta \gamma)_{i k}+(\tau \beta \gamma)_{i j k}+\varepsilon_{i j k l}
$$

$i=1$ and 2. $j=1$ and $2 . k=1$ and 2 for this particular case. $\mu$, is the overall mean effect. $\tau_{i}, \beta_{j}, \gamma_{k}$, are the effects of the $i$ th level of factor A (particle size), $\left(\sum_{i} \tau_{i}=0\right)$; of the $j$ th level of factor B (temperature), $\left(\sum_{j} \beta_{j}=0\right)$; and, of the $k$ th level of factor $\mathrm{C}(\mathrm{pH}),\left(\sum_{k} \gamma_{k}\right)=0 .(\tau \beta)_{i j},(\tau \gamma)_{i k},(\beta \gamma)_{i k}$ and $(\tau \beta \gamma)_{i j k}$ are the effects of the interactions between $\mathrm{A} \times \mathrm{B}, \mathrm{A} \times \mathrm{C}, \mathrm{B} \times \mathrm{C}$ and $\mathrm{A} \times \mathrm{B} \times \mathrm{C}$, respectively. $\varepsilon_{i j k l}$, is the random error in the combination $i j k l$ and $l$ are the replicates. 
Table 3. CBZ adsorption experiments. A, particle size; B, temperature; C, pH. Factor levels, low $(-1)$, high (+1).

\begin{tabular}{ccccccc}
\hline \multirow{2}{*}{ Run } & \multicolumn{3}{c}{ Coded Factors } & \multicolumn{3}{c}{ Percent of CBZ Removal } \\
\cline { 2 - 7 } & A & B & C & Replicate 1 & Replicate 2 & Replicate 3 \\
\hline 1 & -1 & -1 & -1 & 11 & 10.6 & 12.1 \\
2 & 1 & -1 & -1 & 12 & 8.3 & 6.5 \\
3 & -1 & 1 & -1 & 9.8 & 12.2 & 10 \\
4 & 1 & 1 & -1 & 5.2 & 5.2 & 5.2 \\
5 & -1 & -1 & 1 & 9.4 & 9 & 10.1 \\
6 & 1 & -1 & 1 & 6.1 & 6.1 & 6.1 \\
7 & -1 & 1 & 1 & 12.8 & 14.7 & 14.2 \\
8 & 1 & 1 & 1 & 2.8 & 2.8 & 2.8 \\
\hline
\end{tabular}

According to the ANOVA (Table 4), out of the three factors, only the particle size was significant $(p<0.05)$ for CBZ adsorption, confirming that PS1 functions better that PS2 as was aforementioned with regard to Figure 4. However, even more important, the interaction between the evaluated three factors (particle size, temperature, and $\mathrm{pH}$ ) was significant $(p<0.05)$, and the best experimental conditions for CBZ adsorption onto tezontle was the combination of PS1, $\mathrm{pH} 8$, and $25^{\circ} \mathrm{C}$. Under such conditions, the lowest equilibrium concentration and the corresponding highest removal of CBZ was reached (Table 2). It is important to point out that although the adsorptive capacity of tezontle was found to be low, the contribution of this porous medium to CBZ removal remains important because of the quantity of filter medium required in CWs, as well as the concentration of this drug in wastewater.

Table 4. Results from the ANOVA for CBZ adsorption.

\begin{tabular}{cc}
\hline Factors & $p$-Value \\
\hline A: Particle size & 0.0000 \\
B: Temperature & 0.1220 \\
C: $\mathrm{pH}$ & 0.0749 \\
$\mathrm{AB}$ & 0.0000 \\
$\mathrm{AC}$ & 0.0034 \\
$\mathrm{BC}$ & 0.0141 \\
$\mathrm{ABC}$ & 0.0343 \\
\hline
\end{tabular}

The increase in tezontle adsorption capacity with temperature is probably due to the fact that temperature enhances the mobility of organic compounds, which may lead to a higher adsorption [15]. Nevertheless, this behavior was only observed in this particular case (PS1, pH 8), while in the other cases the adsorption capacity decreased with the increase in temperature. In this way, apparently temperature does not have a unique effect on the adsorption of CBZ onto tezontle. On the other hand, a better result at $\mathrm{pH} 8$ in comparison to $\mathrm{pH} 6$ coincides with the findings of other authors who affirm that under acidic conditions, the positively-charged adsorbent surface do not favor pharmaceutical sorption [13], in particular for neutral-organic compounds, such as CBZ [2].

With respect to the kinetic of the adsorption of CBZ on tezontle, the two most common models were evaluated, i.e., Lagergren pseudo-first-order model (Equation (2)) and pseudo second-order model (Equation (3)).

$$
\begin{gathered}
\operatorname{In}\left(q_{e}-q_{t}\right)=\operatorname{In}\left(q_{e}\right)-K_{1} t \\
\frac{t}{q_{t}}=\frac{1}{K_{2} q_{e}{ }^{2}}+\frac{t}{q_{e}}
\end{gathered}
$$

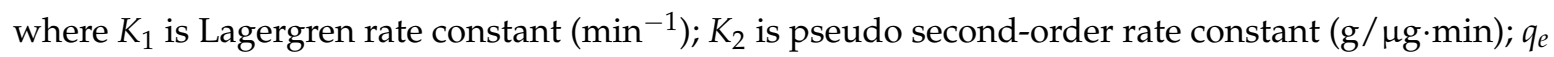
and $q_{t}$ are the amount of pollutant adsorbed at equilibrium $(\mu \mathrm{g} / \mathrm{g})$ and at time $t(\mathrm{~min})$, respectively. 
The pseudo-first-order model assumes a proportional relation for the rate of adsorption, while the pseudo-second-order equation suggests that the rate of adsorption is proportional to the square of the number of unoccupied sites [34]. According to the correlation coefficient $R^{2}$, the pseudo-first order model does not fit well to the data obtained from the experiments (Table 5). In contrast, a better fit to pseudo-second order model was found for all assays (Table 5), which suggests a CBZ chemisorption $[35,36]$ onto tezontle.

The previous results were confirmed through the quantification of actives sites (in PS1), which determines the extent of a chemisorption process [37]. Similar to activated carbons [38], both acid and basic sites were found, in this case in 0.087 and $0.147 \mathrm{meq} / \mathrm{g}$, respectively. Due to the capability of the carboxamide group present in the molecule of $\mathrm{CBZ}$, in particular the $-\mathrm{NH}_{2}$ group of forming hydrogen bond [39], one probable mechanism for CBZ adsorption was the formation of hydrogen bonds with $\pi$ electrons from BAS on the tezontle surface. From studies on carbon surfaces, it has been found that basic properties are associated with Lewis sites located at the $\pi$ electron-rich regions [38], characteristic of oxygen-containing functionality capable of acting as a basic center [40]. In this case, the presence of oxygen in a tezontle surface could be due to its main components, i.e., quartz and ferric oxides [32].

Table 5. Kinetic parameters for adsorption of CBZ onto tezontle at different experimental conditions.

\begin{tabular}{|c|c|c|c|c|c|c|c|}
\hline \multirow{2}{*}{\multicolumn{2}{|c|}{$\begin{array}{l}\text { Experimental } \\
\text { Conditions }\end{array}$}} & \multicolumn{3}{|c|}{ Pseudo First-Order } & \multicolumn{3}{|c|}{ Pseudo Second-Order } \\
\hline & & $\begin{array}{c}K_{1} \\
\left(\min ^{-1}\right)\end{array}$ & $\begin{array}{c}q_{e} \\
(\mu \mathrm{g} / \mathrm{g})\end{array}$ & $\mathbf{R}^{2}$ & $\begin{array}{c}K_{2} \\
(\mathrm{~g} / \mu \mathrm{g} \cdot \min )\end{array}$ & $\begin{array}{c}q_{e} \\
(\mu \mathrm{g} / \mathrm{g})\end{array}$ & $\mathbf{R}^{2}$ \\
\hline \multicolumn{8}{|c|}{ PS1, 0.85-2.0 mm } \\
\hline \multirow{2}{*}{$16^{\circ} \mathrm{C}$} & $\mathrm{pH} 6$ & 0.0076 & 2.48 & 0.09 & 0.157 & 2.51 & 0.97 \\
\hline & $\mathrm{pH} 8$ & 0.0196 & 2.73 & 0.53 & 0.481 & 2.63 & 0.98 \\
\hline \multirow{2}{*}{$25^{\circ} \mathrm{C}$} & $\mathrm{pH} 6$ & 0.0106 & 2.3 & 0.11 & 0.036 & 2.45 & 0.96 \\
\hline & $\mathrm{pH} 8$ & 0.0099 & 3.48 & 0.43 & 0.088 & 3.2 & 0.97 \\
\hline \multicolumn{8}{|c|}{ PS2, $4.0-4.75 \mathrm{~mm}$} \\
\hline \multirow{2}{*}{$16^{\circ} \mathrm{C}$} & $\mathrm{pH} 6$ & 0.0268 & 2.03 & 0.4 & 0.241 & 2.03 & 1 \\
\hline & $\mathrm{pH} 8$ & 0.0307 & 1.7 & 0.84 & 0.29 & 1.61 & 0.93 \\
\hline \multirow{2}{*}{$25^{\circ} \mathrm{C}$} & $\mathrm{pH} 6$ & 0.0182 & 1.3 & 0.65 & 0.63 & 1.25 & 0.96 \\
\hline & $\mathrm{pH} 8$ & 0.0079 & 0.61 & 0.16 & 0.21 & 0.62 & 0.96 \\
\hline
\end{tabular}

\subsection{Adsorption Kinetic Assays of CBZ onto Tezontle with Biofilm}

The characteristics of the sedimented wastewater used to promote biofilm formation on the tezontle with PS1 inside the columns are shown in Table 6. The characteristics were similar to those of the wastewater used in pilot-scale hybrid wetlands for CBZ removal [9].

Table 6. Characteristics of the wastewater fed to glass columns for biofilm growth on the tezontle (Average $\pm \mathrm{SD}, n=15$ ).

\begin{tabular}{cc}
\hline Chemical Oxygen Demand, mg/L & $107.7 \pm 66.37$ \\
Biochemical Oxygen Demand, mg/L & $45.9 \pm 20$ \\
Total Nitrogen, mg/L & $77.4 \pm 44.23$ \\
Phosphorous, mg/L & $6.8 \pm 3.42$ \\
Total Suspended Solids, $\mathrm{mg} / \mathrm{L}$ & $35.1 \pm 18.15$ \\
Electrical Conductivity, $\mu \mathrm{S} / \mathrm{cm}$ & $873.9 \pm 315.92$ \\
$\mathrm{pH}$ & $7.8 \pm 0.24$ \\
\hline
\end{tabular}

Similar to the essays with tezontle without biofilm growth, the time for the equilibrium to be reached was $120 \mathrm{~min}$ for all of the assays. However, the CBZ equilibrium concentrations varied according to the exposition period of tezontle to wastewater. In general, the higher the time of exposition, the larger the adsorption capacity (Figure 5). These results indicate a modification on the basal state of contact surface of tezontle when being exposed to wastewater and suggest the presence 
of biofilm. It is recognized that the presence of biofilm implies the attachment and deposition of extracellular polymeric substances (EPS) along with bacterial cells and this complex matrix modify the physicochemical characteristics of carrier surfaces [41]. Moreover, the evolution in the sorption capacity of tezontle is probably related to the time required for the biofilm growth. Although the biofilm formation begins within a few minutes, the complete process to reach a mature biofilm capable of produce EPS, responsible of the sorption process, might require days [42].

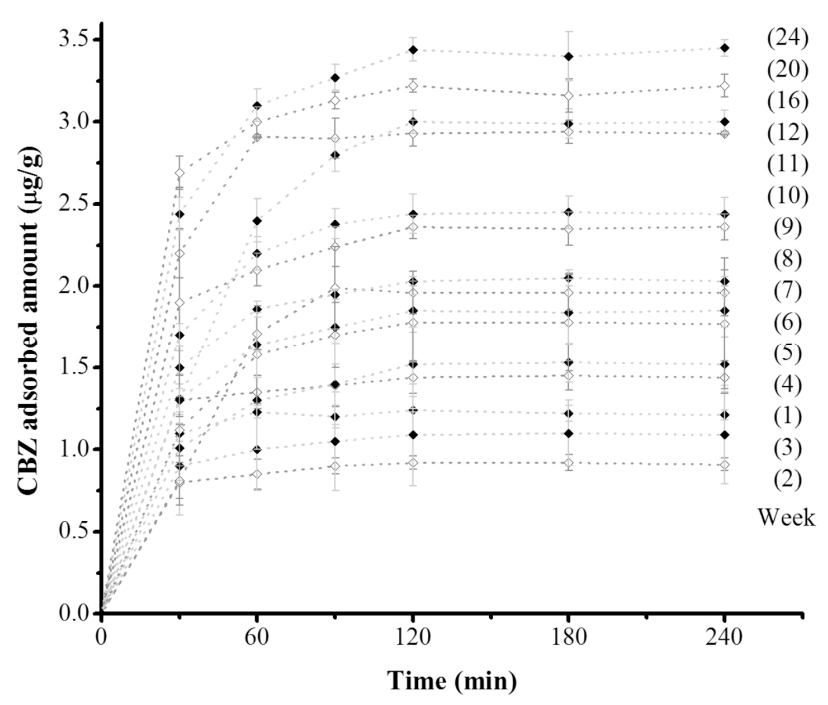

Figure 5. Adsorption kinetics of CBZ onto tezontle with different periods of biofilm formation. Error bars represent standard error of triplicates.

On the other hand, despite the increase in the adsorption capacity of tezontle along the time, with a noticeable increase in the removal percent of CBZ, the maximum value reached after 24 weeks was smaller than the value obtained with tezontle without biofilm. Figure 6 shows increments in the percent of CBZ removal, almost with a linear tendency $\left(R^{2}=0.95\right)$ over time, starting in the second week until the end of the experiment. These results suggest that the removal percentage could probably reach and possibly surpass that obtained with free-biofilm tezontle with larger periods for biofilm growth.

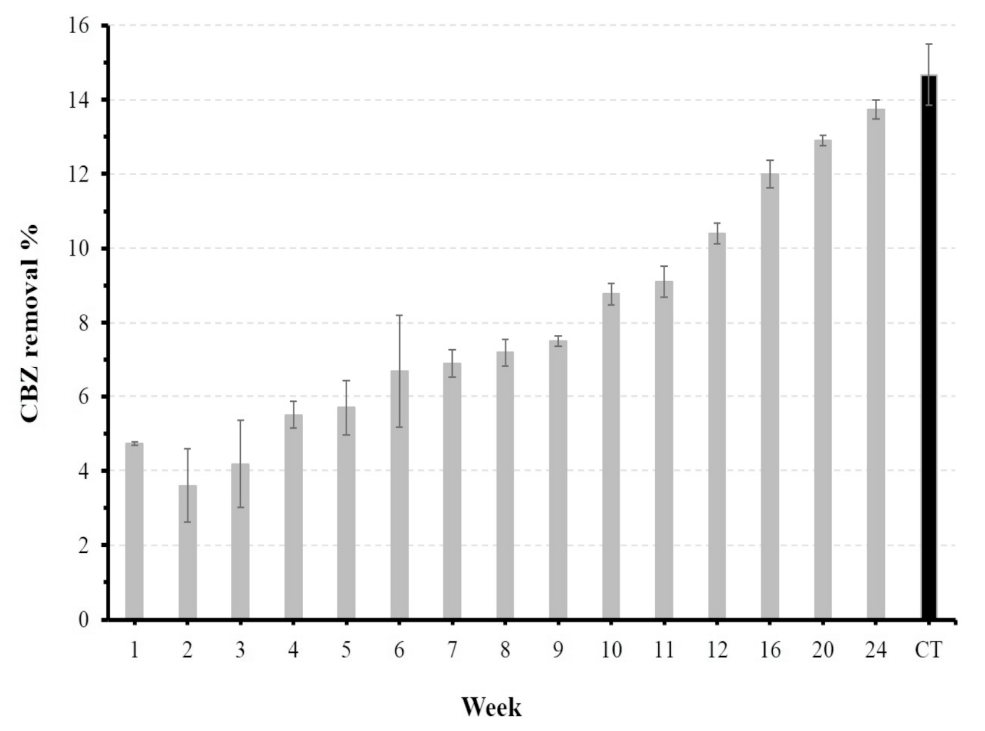

Figure 6. CBZ removal percentage (mean \pm standard error) by tezontle with different periods of biofilm formation and clean tezontle (CT). 
Furthermore, as expected, the experimental data obtained from each adsorption kinetic showed a better fit to pseudo-second order kinetic model (Table 7) alike to the adsorption kinetic with free-biofilm tezontle, indicating a chemisorption process. Once more, these results were confirmed through the quantification of active sites in each sample of tezontle with biofilm growth, throughout the study. After the first week, the concentration of BAS as well as the concentration of AAS showed a visible decrease in comparison to the concentration in free-biofilm tezontle and then, even more after two weeks (Figure 7); possibly as a consequence of the coating of basal active sites in the tezontle surface by bacterial attachment which changed its physicochemical characteristics as was aforementioned.

After this general reduction in the active sites concentration, the AAS showed a slight increase during the next two weeks and then, a clear tendency of decreasing until almost its disappearance after $\sim 10$ weeks, suggesting their minimal contribution to the adsorption process. In contrast, a noticeable increase was found in the BAS concentration along the time, suggesting that the BAS presence after the second week was due to the biofilm growth onto the tezontle exposed to wastewater and specifically, due to the release of EPS by forming-biofilm microbes. EPS are high-molecular-weight molecules consisting mainly of polysaccharides (40\%), DNA, proteins, lipids, and humic acids [41,43]. Charged or hydrophobic polysaccharides and proteins are particularly responsible of organic compound sorption [44]. Some specific polysaccharide monomers detected by Andersson et al. [45] in EPS released by microbial consortia developed in wastewater are rhamnose, arabinose, galactose, glucose, mannose, ribose among others. In this way, this chemical structures with large $\pi$ electron-rich region could have participated in the CBZ chemisorption process through hydrogen bonds [23]. In addition, a clear relationship was observed between BAS concentration and CBZ removal percent, highlighting this pathway as the main mechanism of adsorption.

The presence of biofilm on tezontle was confirmed through FTIR analysis by which the presence of characteristic biofilms peaks was observed (Figure 8). The small bands between 2900 and $3000 \mathrm{~cm}^{-1}$ are related to $\mathrm{C}-\mathrm{H}$ stretching vibration [41] associated with bacterial biomass [46], whereas the peak at around $2400 \mathrm{~cm}^{-1}$ is due to the vibration of C-O functional groups likely from carboxylic acids which has been reported as a sorption active site present in the cell wall of Gram-positive bacteria [46]. Other characteristic biofilm bands corresponding to proteins (1637-1660 and 1272-1288 cm${ }^{-1}$ ) and polysaccharides (1000-1132 $\mathrm{cm}^{-1}$ ) have been reported in the literature [41]; however, in this study they were not detected, apparently because of the wide and intense bands in the tezontle FTIR fingerprint between 400 and $1750 \mathrm{~cm}^{-1}$, which interfered with the detection of these bands.

Table 7. Kinetic parameters for adsorption of CBZ onto tezontle with biofilm.

\begin{tabular}{ccccccc}
\hline $\begin{array}{c}\text { Weeks of Biofilm } \\
\text { Formation }\end{array}$ & \multicolumn{3}{c}{ Pseudo First-Order } & \multicolumn{3}{c}{ Pseudo Second-Order } \\
\cline { 2 - 7 } & $\begin{array}{c}\boldsymbol{K}_{\mathbf{1}} \\
\left(\mathbf{m i n}^{-1}\right)\end{array}$ & $\begin{array}{c}\boldsymbol{q}_{\boldsymbol{e}} \\
(\boldsymbol{\mu} \mathbf{g} / \mathbf{g})\end{array}$ & $\mathbf{R}^{\mathbf{2}}$ & $\begin{array}{c}\boldsymbol{K}_{\mathbf{2}} \\
(\mathbf{g} / \boldsymbol{\mu g} \cdot \mathbf{m i n})\end{array}$ & $\begin{array}{c}\boldsymbol{q}_{\boldsymbol{e}} \\
(\boldsymbol{\mu} \mathbf{g} \mathbf{g})\end{array}$ & $\mathbf{R}^{\mathbf{2}}$ \\
\hline 1 & 0.0212 & 1.22 & 0.5 & 3.5 & 1.25 & 0.99 \\
2 & 0.0265 & 0.9 & 0.61 & 8.6 & 0.91 & 0.99 \\
3 & 0.0048 & 1.09 & 0.53 & 0.035 & 0.9 & 0.90 \\
4 & 0.0198 & 1.44 & 0.6 & 0.99 & 1.5 & 0.99 \\
5 & 0.006 & 1.52 & 0.66 & 0.068 & 1.51 & 0.96 \\
6 & 0.0048 & 1.78 & 0.054 & 0.31 & 1.8 & 0.97 \\
7 & 0.0285 & 1.78 & 0.92 & 0.061 & 1.7 & 0.99 \\
8 & 0.0049 & 1.96 & 0.34 & 0.058 & 1.86 & 0.96 \\
9 & 0.0107 & 2.03 & 0.12 & 0.044 & 2.4 & 0.98 \\
10 & 0.0069 & 2.36 & 0.07 & 2.8 & 1.9 & 0.97 \\
11 & 0.006 & 2.44 & 0.18 & 1.26 & 2.39 & 0.99 \\
12 & 0.0106 & 2.93 & 0.75 & 0.14 & 2.61 & 0.99 \\
16 & 0.0181 & 3.0 & 0.84 & 0.0048 & 3.01 & 0.90 \\
20 & 0.0049 & 3.22 & 0.096 & 0.072 & 3.27 & 0.99 \\
24 & 0.0216 & 3.44 & 0.88 & 0.037 & 3.55 & 0.99 \\
\hline
\end{tabular}




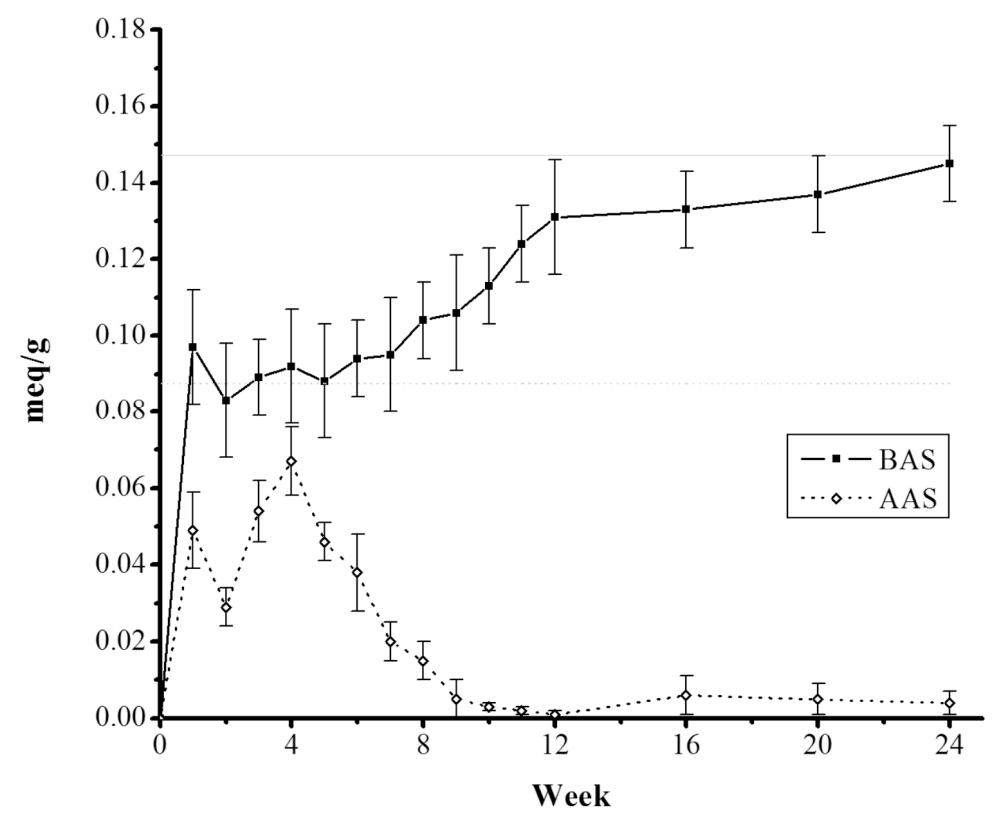

Figure 7. Concentration of active sites (mean \pm standard error) by week of biofilm development, basic active sites (BAS) and acid active sites (AAS). Control concentration at 0.147 and $0.087 \mathrm{meq} / \mathrm{g}$, respectively.

On the other hand, there is a clear difference between the spectra of free-biofilm tezontle and those of tezontle with biofilm growth, in the sense that the first one does not present the aforementioned bands that showed a noticeable evolution in the FTIR spectra along the time of experimentation.

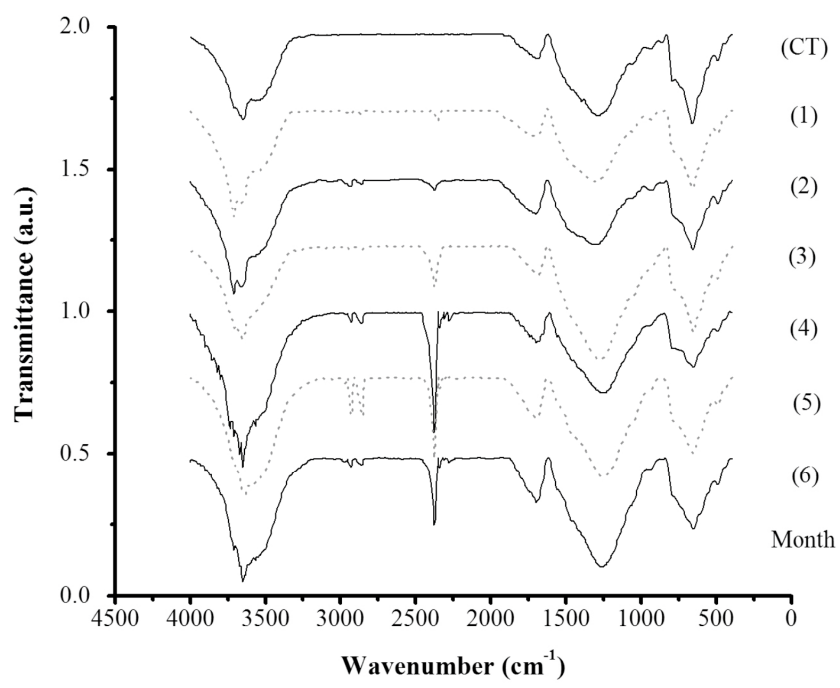

Figure 8. Infrared spectra of tezontle PS1 with biofilm development by month and clean tezontle (CT).

Finally, the FE-SEM micrographs revealed the presence of bridge-shape structures on the tezontle surface, which have been reported as a common physical structure of biofilms whose number usually increases through the time [47]. A comparison between free-biofilm tezontle and tezontle with two different periods of biofilm development (4 and 24 weeks) shows the highest density of biomass after 24 weeks (Figure 9). 


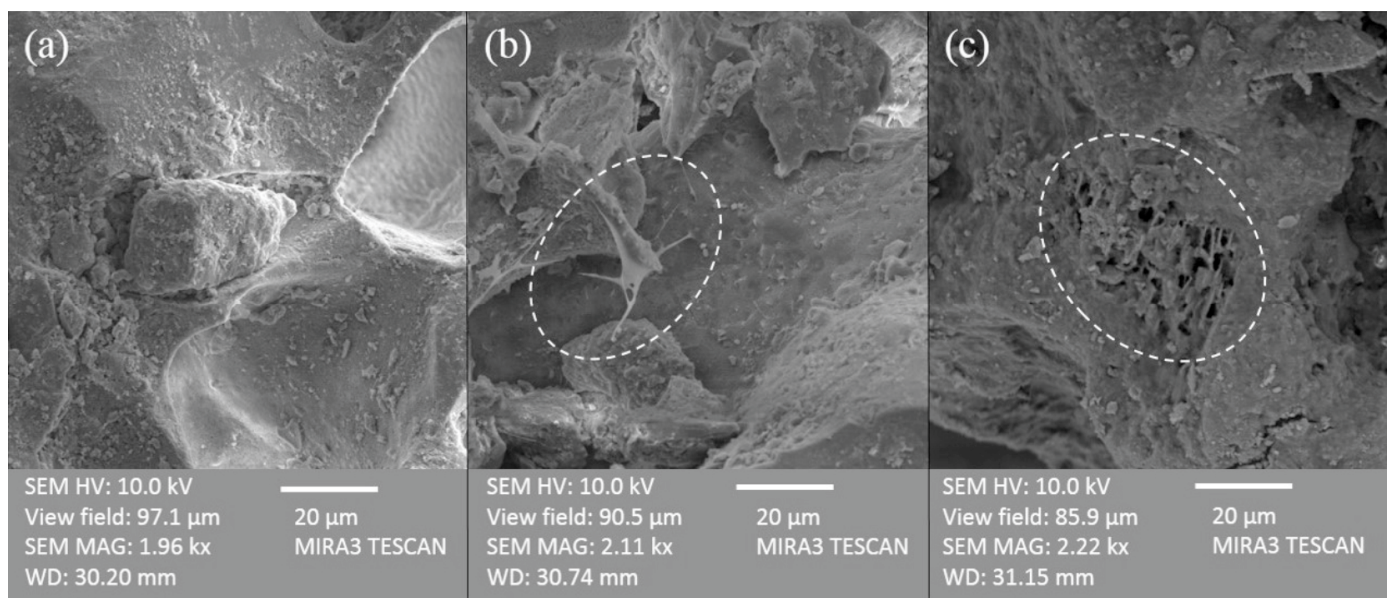

Figure 9. FE-SEM images of tezontle, (a) clean tezontle; (b) tezontle after 4 weeks of exposition to wastewater; and, (c) tezontle after 24 weeks of exposition to wastewater.

\section{Conclusions}

Tezontle, a common porous-filter medium for CWs in Mexico, was found to have some capacity for CBZ chemisorption through the presence of both AAS and BAS. This capacity was modified with biofilm formation; after an initial decrease in tezontle capacity, chemisorption took place through the EPS released by microbial consortia, which generated BAS (Lewis sites located at the $\pi$ electron-rich regions). An increase in the adsorption capacity of tezontle with biofilm was obtained along the period of experimentation, with a tendency to possibly reach and maybe surpass the capacity of clean tezontle. These results confirm the essential role that filter media used in CWs might play for pharmaceutical removal.

Acknowledgments: Graduate scholarship for Allan Tejeda was provided by National Council for Science and Technology of México.

Author Contributions: F. Zurita conceived and designed the experiments; A. Tejeda performed the experiments, analyzed the data and wrote the paper under the supervision of F. Zurita; A. Barrera contributed to the manuscript with the material characterization and the analysis of the corresponding data.

Conflicts of Interest: The authors declare no conflict of interest.

\section{References}

1. Zhang, Y.; Geißen, S.U.; Gal, C. Carbamazepine and diclofenac: Removal in wastewater treatment plants and occurrence in water bodies. Chemosphere 2008, 73, 1151-1161. [CrossRef] [PubMed]

2. Dordio, A.V.; Estêvão Candeias, A.J.; Pinto, A.P.; Teixeira da Costa, C.; Palace Carvalho, A.J. Preliminary media screening for application in the removal of clofibric acid, carbamazepine and ibuprofen by ssf-constructed wetlands. Ecol. Eng. 2009, 35, 290-302. [CrossRef]

3. Fent, K.; Weston, A.A.; Caminada, D. Ecotoxicology of human pharmaceuticals. Aquat. Toxicol. 2006, 76, 122-159. [CrossRef] [PubMed]

4. Li, W.C. Occurrence, sources, and fate of pharmaceuticals in aquatic environment and soil. Environ. Pollut. 2014, 187, 193-201. [CrossRef] [PubMed]

5. Clara, M.; Strenn, B.; Ausserleitner, M.; Kreuzinger, N. Comparison of the behaviour of selected micropollutants in a membrane bioreactor and a conventional wastewater treatment plant. Water Sci. Technol. 2004, 50, 29-36. [PubMed]

6. Li, Y.; Zhu, G.; Ng, W.J.; Tan, S.K. A review on removing pharmaceutical contaminants from wastewater by constructed wetlands: Design, performance and mechanism. Sci. Total Environ. 2014, 468-469, 908-932. [CrossRef] [PubMed] 
7. Ternes, T.A. Occurrence of drugs in german sewage treatment plants and rivers. Water Res. 1998, 32, 3245-3260. [CrossRef]

8. Zhang, D.; Gersberg, R.M.; Ng, W.J.; Tan, S.K. Removal of pharmaceuticals and personal care products in aquatic plant-based systems: A review. Environ. Pollut. 2014, 184, 620-639. [CrossRef] [PubMed]

9. Tejeda, A.; Torres-Bojorges, Á.X.; Zurita, F. Carbamazepine removal in three pilot-scale hybrid wetlands planted with ornamental species. Ecol. Eng. 2017, 98, 410-417. [CrossRef]

10. Matamoros, V.; Caselles-Osorio, A.; García, J.; Bayona, J.M. Behaviour of pharmaceutical products and biodegradation intermediates in horizontal subsurface flow constructed wetland. A microcosm experiment. Sci. Total Environ. 2008, 394, 171-176. [CrossRef] [PubMed]

11. Mailler, R.; Gasperi, J.; Coquet, Y.; Derome, C.; Buleté, A.; Vulliet, E.; Bressy, A.; Varrault, G.; Chebbo, G.; Rocher, V. Removal of emerging micropollutants from wastewater by activated carbon adsorption: Experimental study of different activated carbons and factors influencing the adsorption of micropollutants in wastewater. J. Environ. Chem. Eng. 2016, 4, 1102-1109. [CrossRef]

12. Suriyanon, N.; Permrungruang, J.; Kaosaiphun, J.; Wongrueng, A.; Ngamcharussrivichai, C.; Punyapalakul, P. Selective adsorption mechanisms of antilipidemic and non-steroidal anti-inflammatory drug residues on functionalized silica-based porous materials in a mixed solute. Chemosphere 2015, 136, 222-231. [CrossRef] [PubMed]

13. Zhang, S.; Dong, Y.; Yang, Z.; Yang, W.; Wu, J.; Dong, C. Adsorption of pharmaceuticals on chitosan-based magnetic composite particles with core-brush topology. Chem. Eng. J. 2016, 304, 325-334. [CrossRef]

14. Jiang, M.; Yang, W.; Zhang, Z.; Yang, Z.; Wang, Y. Adsorption of three pharmaceuticals on two magnetic ion-exchange resins. J. Environ. Sci. 2015, 31, 226-234. [CrossRef] [PubMed]

15. Thiebault, T.; Guégan, R.; Boussafir, M. Adsorption mechanisms of emerging micro-pollutants with a clay mineral: Case of tramadol and doxepine pharmaceutical products. J. Colloid Interface Sci. 2015, 453, 1-8. [CrossRef] [PubMed]

16. Imfeld, G.; Braeckevelt, M.; Kuschk, P.; Richnow, H. Monitoring and assessing processes of organic chemicals removal in constructed wetlands. Chemosphere 2009, 74, 349-362. [CrossRef] [PubMed]

17. Matamoros, V.; García, J.; Bayona, J.M. Behavior of selected pharmaceuticals in subsurface flow constructed wetlands: A pilot-scale study. Environ. Sci. Technol. 2005, 39, 5449-5454. [CrossRef] [PubMed]

18. Day, P.R. Particle fractionation and particle-size analysis. In Methods of Soil Analysis; Black, C.A., Evans, D.D., Ensminger, L.E., White, J.L., Clark, F.E., Eds.; American Society of Agronomy: Madison, WI, USA, 1965; pp. 545-567.

19. Brix, H.; Arias, C.A.; Del Bubba, M. Media selection for sustainable phosphorous removal in subsurface flow constructed wetlands. Water Sci. Technol. 2001, 44, 47-54. [PubMed]

20. Qin, X.; Liu, F.; Wang, G.; Li, L.; Wang, Y.; Weng, L. Modeling of levofloxacin adsorption to goethite and the competition with phosphate. Chemosphere 2014, 111, 283-290. [CrossRef] [PubMed]

21. American Public Health Association; American Water Works Association; Water Environment Federation. Standard Methods for the Examination of Water and Wastewater, 21st ed.; American Public Health Association: Washington, DC, USA, 2005.

22. Haughton, P.N.; Grau, E.G.; Lyng, J.; Cronin, D.; Fanning, S.; Whyte, P. Susceptibility of campylobacter to high intensity near ultraviolet/visible $395+/-5 \mathrm{~nm}$ light and its effectiveness for the decontamination of raw chicken and contact surfaces. Int. J. Food Microbiol. 2012, 159, 267-273. [CrossRef] [PubMed]

23. Boehm, H.P. Some aspects of the surface chemistryof carbon blacks and other carbons. Carbon 1994, 35, 759-769. [CrossRef]

24. Leyva, R.; Díaz, P.E.; Guerrero, R.M.; Mendoza, J.; Aragón, A. Adsorción de cd(ii) en solución acuosa sobre diferentes tipos de fibras de carbón activado. J. Mex. Chem. Soc. 2004, 48, 169-202.

25. Vymazal, J.; Kröpfelová, L. Wastewater Treatment in Constructed Wetlands with Horizontal Sub-Surface Flow; Springer: Dordrecht, The Netherlands, 2008; Volume 14.

26. Alemayehu, E.; Lennartz, B. Adsorptive removal of nickel from water using volcanic rocks. Appl. Geochem. 2010, 25, 1596-1602. [CrossRef]

27. Sing, K.S.W.; Everett, D.H.; Haul, R.A.W.; Moscou, L.; Pierotti, R.A.; Rouquérol, J.; Siemieniewska, T. Reporting physisorption data for gas/solid systems with special reference to the determination of surface area and porosity. Pure Appl. Chem. 1985, 57, 603-619. [CrossRef] 
28. Lowell, S.; Shields, J.E.; Thomas, M.A.; Thommes, M. Characterization of Porous Solids and Powders: Surface Area, Pore Size and Density; Springer: Dordrecht, The Netherlands, 2004; Volume 16.

29. Vilchis-Granados, J.; Granados-Correa, F.; Barrera-Díaz, C.E. Surface fractal dimensions and textural properties of mesoporous alkaline-earth hydroxyapatites. Appl. Surf. Sci. 2013, 279, 97-102. [CrossRef]

30. Brooks, W.E.; Piminchumo, V.; Suárez, H.; Jackson, J.C.; McGeehin, J.P. Mineral pigments at huaca tacaynamo (Chan Chan, Peru). Bull. Inst. Fr. D'études Andin. 2008, 37, 441-450. [CrossRef]

31. Farahmandjou, M.; Soflaee, F. Synthesis and characterization of $\alpha-\mathrm{Fe}_{2} \mathrm{O}_{3}$ nanoparticles by simple co-precipitation method. Phys. Chem. Res. 2015, 3, 191-196.

32. Ponce, B.; Ortiz, A.; Otazo, E.M.; Reguera, E.; Acevedo, O.A.; Prieto, F.; González, C.A. Physical characterization of an extensive volcanic rockin méxico: "Red tezontle" from cerro de la cruz, in tlahuelilpan, hidalgo. Acta Univ. Univ. Guanaj. 2013, 23, 20-27.

33. Gutiérrez Pulido, H.; De la Vara Salazar, R. Análisis y Diseño de Experimentos, 3rd ed.; McGraw-Hill Educación: Mexico City, Mexico, 2012.

34. Ali, R.M.; Hamad, H.A.; Hussein, M.M.; Malash, G.F. Potential of using green adsorbent of heavy metal removal from aqueous solutions: Adsorption kinetics, isotherm, thermodynamic, mechanism and economic analysis. Ecol. Eng. 2016, 91, 317-332. [CrossRef]

35. Chiou, M.S.; Li, H.Y. Equilibrium and kinetic modeling of adsorption of reactive dye on cross-linked chitosan beads. J. Hazard. Mater. 2002, B93, 233-248. [CrossRef]

36. Vadivelan, V.; Kumar, K.V. Equilibrium, kinetics, mechanism, and process design for the sorption of methylene blue onto rice husk. J. Colloid Interface Sci. 2005, 286, 90-100. [CrossRef] [PubMed]

37. Ho, Y.S.; McKay, G. Pseudo-second order model for sorption processes. Process Biochem. 1999, 34, 451-465. [CrossRef]

38. Lopez-Ramon, M.V.; Stoeckli, F.; Moreno-Castilla, C.; Carrasco-Marin, F. On the characterization of acidic and basic surface sites on carbons by various techniques. Carbon 1999, 37, 1215-1221. [CrossRef]

39. Liu, A.; Wang, J.; Lu, Z.; Yao, L.; Li, Y.; Yan, H. Hydrogen-bond detection, configuration assignment and rotamer correction of side-chain amides in large proteins by $\mathrm{nmr}$ spectroscopy through protium/deuterium isotope effects. ChemBioChem 2008, 9, 2860-2871. [CrossRef] [PubMed]

40. Suárez, D.; Menéndez, J.A.; Fuente, E.; Montes-Morán, M.A. Pyrone-like structures as novel oxygen-based organic superbases. Angew. Chem. Int. Ed. 2000, 112, 1376-1379. [CrossRef]

41. Chen, Y.P.; Zhang, P.; Guo, J.S.; Fang, F.; Gao, X.; Li, C. Functional groups characteristics of eps in biofilm growing on different carriers. Chemosphere 2013, 92, 633-638. [CrossRef] [PubMed]

42. Andersson, S. Characterization of Bacterial Biofilms for Wastewater Treatment. Ph.D. Thesis, Royal Institute of Technology, Stockholm, Sweden, 2009.

43. Fang, F.; Lu, W.T.; Shan, Q.; Cao, J.S. Characteristics of extracellular polymeric substances of phototrophic biofilms at different aquatic habitats. Carbohydr. Polym. 2014, 106, 1-6. [CrossRef] [PubMed]

44. Flemming, H.C.; Wingender, J. The biofilm matrix. Nat. Rev. Microbiol. 2010, 8, 623-633. [CrossRef] [PubMed]

45. Andersson, S.; Dalhammar, G.; Kuttuva Rajarao, G. Influence of microbial interactions and eps/polysaccharide composition on nutrient removal activity in biofilms formed by strains found in wastewater treatment systems. Microbiol. Res. 2011, 166, 449-457. [CrossRef] [PubMed]

46. Eduok, U.; Khaled, M.; Khalil, A.; Suleiman, R.; El Ali, B. Probing the corrosion inhibiting role of a thermophilic bacillus licheniformis biofilm on steel in a saline axenic culture. RSC Adv. 2016, 6, 18246-18256. [CrossRef]

47. Melo, L.F. Biofilm formation and its role in fixed film processes. In Handbook of Water and Wastewater Microbiology; Mara, D., Horan, N., Eds.; Academic Press: London, UK, 2003; pp. 337-349.

(C) 2017 by the authors. Licensee MDPI, Basel, Switzerland. This article is an open access article distributed under the terms and conditions of the Creative Commons Attribution (CC BY) license (http:/ / creativecommons.org/licenses/by/4.0/). 